\title{
TRAVELLING IDEOLOGIES: A STORY OF WHITENESS
}

\author{
OA N A C O G E A N U \\ Alexandru Ioan Cuza University of Iaşi, Romania
}

\begin{abstract}
Prompted by the observations of a European scholar in African-American studies living in South-East Asia, this article addresses the ideological value of whiteness with a view to understanding its apparently global aesthetic fascination and societal power. To this purpose, the article traces the European, American and Asian conceptualization and employment of the signs of whiteness. The first section investigates the correlated philosophical and scientific construction of whiteness as a racial signifier in Europe. The second section focuses on social and cultural practices of white vs. black identification and the critique thereof in the United States. The third section highlights the appeal of whiteness as a status signifier in Asia. Whiteness is commonly employed as a sign of superiority, assumed by the self or assigned to the other (within): the article suggests that such power derives from a common mystical symbolism, upheld by philosophy, sanctioned by science, implemented by social policy and marketed by corporations.
\end{abstract}

Key words: white, black, ideology, African-American, South-East Asia

\section{Introduction: a Scene}

On a university campus in Seoul, South Korea, a Brazilian professor is teaching an Egyptian boy how to play an American game where one has to identify the people on the other's cards by asking questions about their appearance. "Are you black?" the professor asks. "No, I am white," the boy responds. "Then turn face down all the cards with black people," explains the professor. The boy selects four cards. "That's not right," the professor corrects him, indicating more cards. The two seem to disagree on what a black or white person should look like, and the boy soon gives up playing.

This casual scene I witnessed engenders longstanding cultural and societal issues related, among other things, to the perception and significance of whiteness, which I will address in this article. I will trace how the opposition of whiteness and blackness on which this scene builds was culturally constructed in the first place. Then, I will discuss its contextualization in the American card game, played in this particular case by a Latin American instructor and an African learner. Subsequently, I will place the discussion of whiteness in the 
East-Asian setting of the game. The aim of this mise-en-scene is to investigate how whiteness is conceptualized and played out in various contexts, with a view to understanding its apparently transcontinental normative power.

This article surveys the construction and employment of the ideology of whiteness in Europe, America and Asia. The article is divided into three main sections, dealing with the European, American and Asian conceptualizations of whiteness. The first section, "The invention of whiteness," investigates the correlated philosophical and scientific establishment of whiteness as a racial signifier. The second section, "The institutionalization of whiteness: opposing blackness," focuses on societal and cultural practices of color-based (self-) identification and the critique thereof in the United States. The third part, "Commodifying whiteness," highlights the technologized appeal of whiteness as a status sign being marketed in Asia. This transcontinental survey finds that, whether defined as a given feature to be observed or a possible ideal to be attained, whiteness is commonly employed as a sign of superiority - assumed by the self or assigned to the other. I suggest that the normative power of whiteness is based on a common mystical symbolism, upheld by philosophy, sanctioned by science, implemented by policy and promoted by technology, and eventually derives from its invisibility and virtuality; contextually filled with racial, societal and aesthetic meaning, whiteness continues to be enforced on the body in a desire for illumination.

\section{The Invention of Whiteness}

Among the physical traits of human beings, the color of one's skin is afforded particular significance. In the card game mentioned above, the first question was about skin color as a basic criterion for distinction. Whereas the boy may have had a keener eye to differences in complexion and was therefore unable to clearly distinguish "black" from "white," the professor bore a more simplified taxonomy in mind: the racial one. Before notions of different races could become "common sense," "the idea of race had to be invented, described, promulgated and legislated by those who would benefit as a group from the concept" (Nelson viii-ix). The existence of the Caucasoid, Negroid and Mongoloid races usually passes as a scientific fact based on objective observation of geographical distribution and physical characteristics including skin color, and is employed in scientific discourse with(out) an awareness of qualitative implications. However, the term "Caucasian race" was coined in the eighteenth century by a German philosopher, Christoph Meiners, and gained currency through the work of anthropologist J. F. Blumenbach, who explained having taken the name of this variety from Mount Caucasus because it produces "the most beautiful race of men" (Blumenbach 23). This taxonomic choice involves an aesthetic judgement conflating beauty and whiteness: Caucasians 
have the "whitest, most blooming and most delicate skin", added the scientist (Blumenbach 28).

Interestingly, in the dawn of Western civilization, documents of the attitudes toward darker complexions suggest the absence of color-based racial discrimination. As concerns, for instance, Greek references to skin color, it has been shown that Herodotus described the physical appearance of Africans idealistically (Snowden 57), whereas the poet Philodemus extolled the perfection of his short, dark-skinned and kinky-haired lover: "May I love such a Philaenion, golden Cypris, until I find another more perfect" (Snowden 77). In fact, both the cities and the art of ancient Greece and Rome were proven to have been rich in color and varied in ethnicity, and the "mystical" belief in the whiteness of Antiquity has been critiqued as a "whitewashed memory" of a spotless Greek heritage, free from all stains of otherness (Jockey 189). However, this does not mean that citizens of the Greek and Roman world and their western-focused aftermath did not maintain narcissistic norms for skin color. To the extent that each group considers itself superior to others, including in terms of appearance, it refers to a somatic norm image, defined by Hoetink as "the complex of physical (somatic) characteristics which are accepted by a group as its ideal" (120). To illustrate the somatic norm image, Hoetink refers to an African creation myth, according to which the African perceives himself as perfectly cooked whereas the European is underdone due to a defect in the Creator's oven. Nevertheless, the somatic norm image is a complex, sometimes refractive construction. First, it is not necessarily made in a group's own image, but in a group's ideal self-image (pushing people of perceived white complexion to aim at a paler shade of whiteness). Second, the somatic norm image asserts itself in opposition to the other, hence the beauty of whiteness is highlighted as opposed to unsightly blackness with the resulting response of the "black is beautiful" movement and the derogatory "white trash". Third, the somatic norm image is apparently able to incorporate the other, as illustrated by the practice of venerating the white stranger in black communities or extolling the exotic black in white groups. Thus the ancient Greeks and Romans themselves, generally of dark hair and light to medium complexion, would bleach their hair and whiten their face with white lead, which effectively gave them a deathly appearance, to achieve an ever whiter beauty ideal, and represented their Olympian gods and the heroes of Antiquity as blue-eyed (Juno) and golden-haired (Achilles).

This Greek and Roman somatic norm image was singled out and passed down throughout European history. Portraits of women during the Middle Ages depict the "realistic ravages of lead poisoning" to which women subjected themselves in order to achieve the whitewashed ideal (Tungate 14). During the Renaissance, a ghostly appearance as displayed, for instance, by Elizabeth I of England, was considered the height of feminine beauty and nobility. This image was adhered to by German Romanticism, enchanted with the otherworldly pallor 
of poetic femininity, and was further spread by the Enlightenment, protective of delicate, domestic femininity. In sun-kissed modernity, the European ideal of a white skin still affects people of a darker complexion due to ethnic or professional contexts (gypsies, outside workers), automatically relegating them to categories liable to social discrimination.

In the development of European white-centrism, the nineteenth century marks an ideological climax: color-bound race was established as a criterion for nothing less than the existence and assessment of civilization and culture. Whereas Europe had always contained the colorful difference of other populations rushing to its cities or conquered by its empires, the age of exploration from the fifteenth to the eighteenth century brings in a new, colonial reality. With the arrival of the first slaves in Lisbon in the fifteenth century and the European colonization of Asia, Africa and America, the emerging social and economic realities require justification. Then, the philosophical justification of race, as surveyed by Appiah (1985), associates the European white race with culture and historical development, as opposed to African nature and Asian immobility.

Thus, according to Taine in The History of English Literature (1864), race was the source of all structures of feeling and thought: "to track the root of man is to consider the race itself $[\ldots]$ the structure of his character and mind, his general processes" (qtd. in Appiah 3). In Of National Characters (1748), Hume asserted the fundamental identity of complexion, character and intellectual capacity, stating that "I am apt to suspect the negroes and in general all the other species of men [...] to be naturally inferior to the whites" because of a presumed lack of arts and science (qtd. in Appiah 8). In his Observations on the Feeling of the Beautiful and Sublime (1764), Kant claims that "so fundamental is the difference between (the black and white) races of man, [...] it appears to be as great in regard to mental capacities as in color" (qtd. in Appiah 10). Echoing Hume and Kant, Hegel claimed that Africans had no history because they had developed no system of writing and/or had not mastered the writing in European languages; without writing, his argument goes, no repeatable sign of the working of reason could exist; without memory or mind, no history could exist; without history, no humanity. To the European mind, Africa thus becomes the necessary opposite: "What we properly understand as Africa, is the Unhistorical, Undeveloped Spirit [....] The History of the World travels from East to West, for Europe is absolutely the end of History, Asia is the beginning" (qtd. in Appiah 1).

Underlain by the philosophical discourse of the Enlightenment as guided by Greek ocular metaphors and required by Western colonialist urges, modern science has promoted and encouraged the activities of observing, comparing, and ordering the physical characteristics of the human body as a means of classification. The leap from the scientific distinction between races to the ideology of racism as "the belief in the inherent superiority of one race over all 
others and thereby the right to dominance" (Lorde 496) was short, if any. The categories used to construct ideas of racial difference have never been purely descriptive; they included an evaluative dimension which, to European eyes, privileged the category of white bodies over other types.

The meanings attributed starting with the eighteenth and nineteenth centuries to (pseudo)scientific racial categories included value judgments about beauty, intellect, morality, emotions, sexuality, etc. Eventually, racist ideas and imagery took two main forms: some defined racial difference in purely negative terms, whereas others celebrated difference from the white norm, most often in the form of primitivism. In the negative representation of the racial other, people of the Negroid race were usually characterized as lazy, less intelligent, hypersexual, physically strong, likely to excel in sports and with a natural sense of rhythm. People of the Mongoloid race were often described as undifferentiated, rigid, physically weak, hypo-sexual, and cruel. In the more positive, primitivist representation, the Other to the white world was seen as closer to nature and more authentic: a noble savage who is more spiritual, intuitive, physical, and sensual than its "white" interpreter. Since such definitions of non-whites are produced via sets of binary hierarchical oppositions, the counterparts to the qualities attributed to people of color, such as rationality, enterprise, intelligence, are assumed to be quintessentially "white." In any case, these negative or positive judgments of racial difference served to justify practices such as slavery, segregation or colonialism and have become part of a set of assumptions that seem to permeate Western cultures to this day.

Whereas contemporary science tends to no longer speak of races due to interbreeding and the disordered distribution of hereditary physical traits, the concept of race and its association with skin color remains important to the extent that it informs individual and collective actions. My witnessed scene shows that present-day conversations and thoughts display usages of race deriving from the philosophy and science of the eighteenth and nineteenth centuries. In spite of the many open claims that race is not a biological or natural category, race is given meaning through the agency of human beings in concrete historical and social contexts and, as such, functions as a very powerful ideology (Roediger 2). As was argued with respect to gender, nation or class, race too is part of such constructed identities based on an alienation "cancelling the particularity of an individual life into collective anonymity," but "the truth remains [...] that such categories, ontologically empty though they may be, continue to exert an implacable force" (Eagleton 24). Race has thus become a signal of irreducible difference between groups that usually also have fundamentally opposed economic interests. As illustrated by the conversation between the Brazilian professor and the Egyptian boy, "race is the ultimate trope of difference because it is so very arbitrary in its application" (Appiah 5). 


\section{The Institutionalization of Whiteness: Opposing Blackness}

Since the scene described in the introduction involves an American card game, the United States provides the specific context of this discussion of whiteness. In the US, the term "Caucasian" is occasionally used to describe a social group that is more commonly referred to as "white people" (Painter 2); in fact, the category "white" appears as an entry for self-identification in the American census (Humes 3).

The idea of color-bound race may be "intimately connected to the cultural, moral, metaphysical and biological landscape of America's history" (Henderson 19), but this is an idea that is both confirmed and invalidated in American society. Heir to European white-centrism, the American conceptualization of race makes one practical step forward by legitimating the superiority of whiteness, in other words, by instrumentalizing blackness. Given the specific historical circumstances of the United States, where the overwhelming presence and economic necessity of black people was a reality impossible to refute, Africans provided an immediate image of blackness against which the European immigrants could contrast their idealized whiteness and on which to project their needs and fears; as a result, in early American (self-) identification, the human(e) whiteness of masters is defined in opposition to the subhuman blackness of slaves.

The American racial differentiation adhered to the notions of whiteness and blackness to the extent that, ironically, skin color became an insufficient criterion for distinguishing between black and white folks. Blackness and whiteness were no longer considered physical features but essential attributes lying under the skin. The need to maintain the conceptual distinction between them resulted in boundary setting legislation, underlain by a paradoxical notion of invisible blackness, designed to counter boundary breaking practices and thus protect the integrity of whiteness. Consequently, color boundaries were guarded by hypodescent rules identifying as black anyone with a given black ancestry fraction and culminating with the one-drop rule applied in the American South in the nineteenth and twentieth centuries. This abstract separation was occasionally breached by the practice of racial passing, where a light-skinned person of African descent would identify as white with the resulting advantages and betrayals (see for instance a testimony of racial passing in James Weldon Johnson's The Autobiography of an Ex-Colored Man); it also turned a blind eye on frequent racial mixing practicing and also provided a profitable solution to forced or willful miscegenation. As an example of this dialectic of color boundaries and transgressions, Abraham Lincoln himself is known to have sired four children who were born into slavery to his mixed-blood servant Sally Hemmings, were later freed and whose descendants identified as white.

Imposed from without, this color-bound racial differentiation was internalized by its object, the black other, and the definition of blackness was 
assumed and reshaped from within in the United States into a presumably distinct, African-American identity. The commonalities of black racial experience that were fashioned in slavery precipitated the emergence of a racial identity in American culture (Dyson xv), better said, the assumption of a black identity: "The quest for racial unity has represented the desperate effort to replace a cultural uprooting that should have not occurred with a racial unanimity that actually never existed" in Africa (Dyson xv). This internalization of a black racial identity, or "epidermelization" as Fanon called it, has occurred both where the black other was transplanted, and where the dark other was native, and has been described sociologically for the United States by the Nigrescence model, which, by way of simplifying, formalizes five stages of "becoming black" (Cross).

The Nigrescence model distinguishes between pre-encounter, where individuals do not refer to race as an important component of their identity; encounter, when individuals are faced with positive or negative experiences or events directly linked to race, which encourages a re-examination of their current identity; immersion/emersion, when the individual becomes extremely pro-black and anti-white, keen on identifying with the black culture; internalization, characterized by a feeling of satisfaction about being black, accompanied by a less idealized view of race; and internalization-commitment, representing those individuals who translate their internalized identities into action. Whereas this model could prove applicable to the (self-)identification of any minority group on ethnic, religious, sexual or other criteria, it ignores the on-going outer and inner negotiation of the meaning of those criteria in the first place and its linearity tautologically oversimplifies identification.

As concerns African-American self-identification as a race, the notion of an atavistic "race-soul" was rejected even by those black scholars who believed in African retentions, since it contributed, at best, to the primitivist formula into which blackness was cast by white-centric thought: "the Negro's primitivism is nine-tenths that of the peasant the world over and has only a remote tropical flavor" (Locke 11). If the black are a race, it is because they have a common race tradition, and each African-American becomes as such just in proportion as $\mathrm{s} /$ he recognizes, knows and reverences that tradition (Locke 12).

Blackness as a racial signifier has been both admitted and challenged within and outside white-centric boundaries. Early such (re)conceptualizations assert blackness as racial destiny: "What, then, is a race?" asks AfricanAmerican sociologist and civil rights activist W. E. B. DuBois in The Conservation of Races (8). It is a "vast family of human beings, generally of common blood and language, always of common history, traditions and impulses" (8), he answers, and further explains: while race differences have followed mainly physical race lines, no mere physical distinctions would really define or explain the deeper differences - the cohesiveness and continuity of 
these groups; it follows that the deeper differences are spiritual, psychical undoubtedly based on the physical, but infinitely transcending them. In proposing a cultural model of blackness, DuBois implicitly certifies its westcentric racial grounds: "The forces that bind together [...] nations are, then, first, their race identity and common blood; secondly, and more important, a common history, common laws and religion, similar habits of thought and a conscious striving together for certain ideals of life" (DuBois 10) and goes on to distinguish at least eight races, in the tradition of eighteenth and nineteenth century (pseudo)science, based on criteria of ethnicity, geography and civilization: Slavs, Teutons, English, Negroes, Romance, Semites, Hindus and Mongolians. Essentializing the black race of African descent, DuBois argues that, although negroes may be American by birth and citizenship, political ideals, language and religion, they are nevertheless still, more importantly, Negroes, members of a vast historic race that from the very dawn of creation has slept, but half awakening in the dark forests of its African fatherland: "We are the first fruits of this new nation, the harbinger of that black to-morrow which is yet destined to soften the whiteness of the Teutonic to-day", he prophesizes a black future (DuBois 13).

Far from the separate black nationhood envisioned by DuBois in Ghana, a dialectic black and white relation emerges in the writings of African-American essayist James Baldwin. His essay Stranger in the Village (1955) announces that "This world is white no longer, and it will never be white again" (158). Instead of evading the color line through his expatriation in Europe, Baldwin comes to understand that the roots of black identity are not to be found in Africa, to but in European thought, where the image of the black as devil was mythically forged, and explains that this difference between human and non-human was recast into the discrimination between human and subhuman in America, where the relationship attained unprecedented complexity because of the reality of cohabitation. Baldwin subsequently argues that America's confrontation of and reliance on the black presence not only "caused the question of the black's humanity, and of his rights therefore as a human being, to become a burning social issue for several American generations of Americans" (153), but also had tremendous effects on the American character: "At the root of the American Negro problem is the necessity of the American white man to find a way of living with the Negro in order to be able to live with himself" (155). This violent white-black dialectic which became the hard fact of American mental and social life has redefined both sides, posits Baldwin, as "the interracial drama acted out on the American continent has not only created a new black man, it has created a new white man, too" (158).

From a psychological perspective, blackness as subconscious projection is explained by the Afro-French psychiatrist and philosopher Franz Fanon in Black Skin, White Masks (1952). "The white man is sealed in his whiteness. // The 
black man in his blackness" (9) is the departure point of Fanon's argument on the disalienation of black people showing that "European civilization is characterized by the presence, at the heart of what Jung calls the collective unconscious, of an archetype: an expression of the bad instincts, of the darkness inherent in every ego, of the uncivilized savage, the Negro who slumbers in every white man" (187). "Sin is Negro as virtue is white" (139) is the mythical association that Fanon, just like Baldwin, identifies at the basis of the EuroAmerican conceptualization of blackness. At the heart of white affirmation lies the repudiation of blackness: "In the remotest depth of the European unconscious an inordinately black hollow has been made in which the most immoral impulses, the most shameful desires lie dormant" (180). As moral consciousness implies a kind of scission, a fracture of consciousness into a bright part and an opposing black part, in order to achieve morality, it is essential that the black vanish from consciousness, articulates Fanon. The foreign, the obscure and the evil all become associated in the mechanism of projection or transference of the undesirable part of one's self, with the consequence that "the Negro is forever in combat with his own image" (194), complicated by the fact that "not only must the black man be black; he must black in relation to the white man" (110).

Writing of black and white relations from a literary and cultural point of view, the African-American author Toni Morrison defines blackness as metaphor in Playing in the Dark: Whiteness and the Literary Imagination (1992), whose central argument is that "race has become metaphorical - a way of referring to and disguising forces, events, classes, and expressions of social decay and economic division far more threatening to the body politic that biological 'race' ever was" (63). Stating that the entire "literature of the United States, like its history, represents commentary on the transformations of biological, ideological, and metaphysical concepts of racial difference" (14), Morrison posits that "a real or fabricated Africanist presence was crucial to [the] sense of Americanness" (6) as "the process of organizing American coherence through a distancing Africanism became the operative mode of a new cultural hegemony" (8). The author argues not only that the fabrication of an Africanist persona is reflexive, constituting "a powerful exploration of the fears and desires that reside in the writerly conscious" (17), but also that "it may be possible to discover, through a close look at literary blackness, the nature - even the cause of literary whiteness" (9). In an argument following-up on those of Baldwin or Fanon, Morrison highlights that the American project of constructing 'the new white man' involved the need to establish difference stemmed not only from the Old World but also from a difference in the New: its claim to freedom vs. the presence of the unfree (48), and was made possible by an ego-reinforcing Africanist presence (45): "it was this Africanism, deployed as rawness and savagery, that provided the staging ground and arena for the elaboration of the 
quintessential American identity", she emphasizes (44). This leads Morrison to posit the "parasitical nature of white freedom" (57): whereas "images of blackness can be evil and protective, rebellious and forgiving, fearful and desirable - all of the self-contradictory features of the self", she concludes, "whiteness, alone, is mute, meaningless, unfathomable, pointless" (59).

"The truth is that there are no races": Appiah makes one step further in revealing the metaphorical, conventional nature of the racial concept: "there is nothing in the world that can do all we ask race to do for us" (35). Since race does not exist as a meaningful criterion within the sciences, "when one speaks of the white race, the black race or the yellow race, one speaks in metaphors", explains Appiah (4). That is why talk of race can be distressing for people who talk of culture seriously: "where 'gross differences' of morphology are correlated with 'subtle differences' of temperament, belief, and intention - it works as an attempt at a metonym for culture; and it does so only at the price of biologising what is culture, or ideology" (36). In Fanon's words: "the Negro is not. Any more than the white man" (231).

This process of reconceptualizing blackness within the African-American community helps to affirm and/or challenge "colonial imperialist paradigms of black identity which represent blackness one-dimensionally in ways that reinforce and sustain white supremacy" and allows, as bell hooks observes, for the affirmation of multiple black identities and varied black experience. Whereas the discourses of whiteness and blackness alike promoted the notion of an 'authentic experience,' hence seeing as 'natural' those expressions of black life which conform to a pre-existing pattern or stereotype, the contemporary AfricanAmerican approaches to blackness are framed by bell hooks in terms of a "resistance struggle" rooted in a "process of decolonization that continually opposes re-inscribing notions of 'authentic' black identity" (11). This resistance to conceptualization in the first place also contributes to turning the gaze upon whiteness. If accepted that "what is often called the black soul is white man's artefact" (Fanon 14), the converse also holds true inasmuch as whiteness only exists in opposition to blackness or other racial colors.

From DuBois to Morrison, African American authors and scholars have denounced the need to hyphenate one's identity in America; when one speaks of race in the US, one speaks of African Americans, Native Americans, Hispanic Americans, Asian Americans; whites do not come into discussion as they are assumed to be the "default race." However, "racial identities are not only Black, Latino, Asian, Native American and so on; they are also white" (Fusco, qtd. in hooks, Looks 39). In Black Looks (1992), bell hooks notes that white people are often shocked when black people "critically assess white people from a standpoint where 'whiteness' is the privileged signifier": "their amazement that black people match white people with a critical 'ethnographic' gaze is itself an expression of racism," she comments (hooks, Looks 10). 
The African-American theoretical engagement with blackness eventually highlights that, in mainstream discourses of race, white functions as the unmarked category; whiteness signifies a norm which is assumed as equivalent to being human and "the initial structure of modern discourse in the West 'secretes' the idea of white supremacy" (West 71), a philosophically concocted and (pseudo)scientifically certified underside of modern discourse. Hence contemporary scholarship on race challenges the assumption that one should only explain the other, Black or Asian races, and not attend to what Theodore Allen has termed "the invention of the white race" (Allen ): "to ignore white ethnicity is to redouble its hegemony by naturalizing it" (Fusco in hooks, Yearning 39).

It follows that blackness cannot be deconstructed unless that deconstruction is extended to the binary oppositional logic of blackness/whiteness itself. As Jonathan Rutherford explains from a cultural point of view, in a similar argument to Franz Fanon's, "binarism operates in the same way as splitting and projection: the center expels its anxieties, contradictions and irrationalities onto the subordinate term, filling it with the antithesis of its own identity", which means that "the Other, in its very alienness, simply mirrors and represents what is deeply familiar to the center, but projected outside of itself" (22). From a societal point of view, Cornel West concludes, in the same vein as Toni Morrison, that "whiteness is a politically constructed category parasitic on blackness" (West 18).

The African American challenge of turning the gaze upon whiteness has led to the recent emergence of whiteness studies, whose purpose is to interrogate whiteness as "the centre of power and privilege from which racialization emanates but which operates more or less invisibly as it constructs itself as both the norm and ideal of what it means to be human" (Steyn \& Conway 284). The emerging whiteness studies have been described as "a vital and necessary corrective to a sociology of race relations that myopically explored color-based racisms with little attempt to reflect on constructions of whiteness" (Nayak 738). However, research into American white experiences and realities is often seen as un-raced, representative of humanity and/or objective, and may give the false impression that whiteness studies is an white-centric tradition (Burgin 15). Nevertheless, as seen above, the critical examination of whiteness has a long black history and the critique of whiteness is not new to peoples of color, who have been surviving, discussing and writing about it for some time (Leonardo 142).

Perhaps white culture's most formidable attribute is its ability to mask itself as a category (McLaren 52). The paradoxical property of the culture of whiteness of being "everything and nothing" (Dyer 39) explains its power to colonize default definitions with respect to class, gender, sexuality, nationality, by means of not only violence and coercion, but also through what has been 
called a "racial grammar" (Bonilla-Silva 174), a behavioral and linguistic distillate of white-centric racial ideology that helps to reproduce it as just the way things are. The irony is that: "whiteness describes not a culture but the absence of culture" (Roediger 13). Nevertheless, what accounts for this fascinating power of whiteness in the first place?

\section{Commodifying Whiteness}

The question above takes us to the secondary context of the game described in the introduction: its setting in South-East Asia. While to EuroAmerican eyes, whiteness is an ethnic or racial category opposed to blackness, in South-East Asia whiteness appears not to have a binary opposite. Asian whiteness is not defined inter-racially, by static opposition, but mostly intraracially, by dynamic hierarchy. The desire for whiteness passed down throughout European history does remain dominant and is visible in cosmetic, medical and/or photo image interventions for color lightening, but is now paralleled by an increasing desire for contemplating and simulating color diversity by means of exotic tourism, the tanning industry and the incorporation of varying beauty standards, as illustrated by People's magazine recent selection of Kenyan actress Lupita Nyong'o as the most beautiful woman in the EuroAmerican world.

Nevertheless, in Asia, whiteness appears to remain the ideal in terms of skin color. On the same South Korean campus referred to in the introduction, female students protect themselves from the sun by using umbrellas to maintain a pale skin; sun block and skin-whitening products can be seen on their desks. This suggests that, more than striving to maintain their natural skin tone by shielding themselves from the sun, women are encouraged to alter their complexion to a lighter shade. In fact, $80 \%-90 \%$ of cosmetics sold in Asian stores and pharmacies are deemed to contain chemicals that will not only protect the skin from sun damage, but in time will also lighten the skin tone (Pan 5). In 2006, sixty-two skin-whitening products were introduced in supermarkets or pharmacies across the Asia-Pacific region (Fuller), and any person who follows beauty magazines and television advertising in the region will agree that modern South-East Asian women are constantly battered with an array of messages to "get white" (Pan 6).

Historically, white skin has been associated with higher social status and wealth in Asia, just like in Europe, for the immediate reason that women of higher class did not have to work outside in the fields and be subjected to the sun's harsh rays, thus preserving the natural pallor of their skin. In East Asia, there is a longstanding belief that pale white skin indicates success and high status: "dating back to ancient culture, pale, even skin implied a dainty and fragile quality that was associated with beauty, as well as the implication of a higher social stature," argues a marketing study (Grubow 1). In this context, 
"whiteness" and "paleness" are considered distinct but related concepts, signifying "both distinction between, and collusion with, the historical myths of paleness associated with feminine discourses of beauty, and 'whiteness' as an imperialist, racialized value of superiority" (Goon and Craven 5).

Several scholars in Asian American studies consider that skin-whitening "seems tied primarily to colonial history, a fascination with whiteness" (Pan 15) and claim that the indigenous standard for attractiveness has been overhauled by "waves of lighter-skinned conquerors" (Fuller), ranging from the Mongols from Central Asia to the colonizers from Europe, as the locals were fascinated by the novelty of the conquerors' whiter skin. However, this "fascination" would suggest the existence of a previous valorization of white skin as linked to superior status and also connects to the foreign and unfamiliar represented by the conquerors. A reason why the general population may have considered lighter, whiter-skinned people, whether local nobles, Asian migrants or European colonizers, a fascinating novelty could be their minimal encounters (Pan 20); it would follow that whiteness is a marker of superior difference, just like in its European conceptualization, just that in the Asian case white superiority is assigned to the other.

However, it should be noted that to Asians, whiteness is not circumscribed to the Caucasoid race. Contemporary meanings of whiteness in Asia are influenced by Western ideologies, but are based on traditional Asian values and beliefs. The aesthetic ideal of white skin in Asia has been shown to predate colonialism and the introduction of Western notions of beauty (Wagatsuma 444). Just like Europe, Asia has a long, common history of utilizing white skin as a key criterion of personal beauty. In Korea, flawless skin like white jade has been preferred, for men and women alike (Jeon, qtd. in Li 445), since the first known Korean dynasty, Gojoseon (2333-108 B.C.E.). Methods for lightening the skin have always been used and in the upper class of the Koyro dynasty (918-1392), children washed their faces with peach flower water to make their skin clean, white, and transparent. According to the creation myth of the Buryat Mongols of South-Central Siberia, where Korean shamanism originated, the first superhuman was born white. Hence in the tradition of Korean shamanism, a person with white skin is respected and people with white skin are told to this day that they look beautiful and noble. In Japan, it was a woman's moral duty to apply white powder to the face since the Edo period (1615-1868) (Ashikari). In India, white skin is considered a mark of caste and is regarded as an asset (Leistikow). In China, where the saying goes that "one white covers three ugliness," "milk-white" skin is a symbol of beauty and Chinese women were said to swallow powdered pearls to become whiter ( $\mathrm{Li} \mathrm{444).} \mathrm{In} \mathrm{the} \mathrm{present-day,}$ whiteness is a source of symbolic cultural capital in Asia that is associated with the upper class, luxury, prestige and success (Rhada). In general, not only does 
skin lightness affect perceptions of a woman's beauty, it also affects her marital prospects, job prospects, social status, and earning potential.

The present-day Asian appraisal of whiteness is a complex, hybrid result of ancient local values, historical imperialist forces and Western colonizing influences. In Korea, for example, on the one hand, preference for light-skinned women predates Western colonialism and, on the other hand, the light-skinned beauty standard in precolonial times should not be read as simply a "local" or "indigenous" construction. Rather, the idea that white(r) is beautiful is already a "transnational" construction; it was influenced by Chinese political domination and cultural impact and consolidated during the Japanese occupation. The subsequent US military control and lasting cultural influence dressed it up in Western clothes and has prepared it for present-day globalized trends.

In today's consumer culture, this long standing ideal of whiteness is once again commodified. The market value of whiteness is measured by the dramatic growth over the past two decades of whitening and lightening skin products, which are the best-selling product categories in the Asian beauty industry ( $\mathrm{Li}$ 448). This highlights a peculiar feature of the conceptualization of whiteness in Asia: the possibility of becoming white(r). Like leisure tanning in Europe and America, skin whitening in Asia, which is mostly targeted at women, shares an underlying premise: the desire for and illustration of affluence. Conformity to a culture's beauty ideals is both a source and a result of social and economic agency and the alteration of skin color is only part of a global trend of body modification that implies the human's success in controlling the body (Miller), and thereby achieving the somatic norm image.

In approaching their Asian consumers, local and global corporations build on the double value of whiteness as Asian and Western (Pan 35). Thus whiteness is claimed to carry an Asian mystical value attainable by the employment Western science. The specifically local symbols associated with skin-whitening products in magazines or television advertisements, such as pearls, milk, snow or light resonate with the Asian viewer at a deeper, quasi-religious level of association. Moreover, white skin is always linked with naturalness; the reason is that natural ingredients create a sense of natural health for consumers; the consequence is a sense of normativity: in "naturalizing" white skin it is implied that this is the natural order of things. While claiming to be natural, white skin is also associated with technological advancement and the adoption of Western advanced technologies. As a result, skin whitening products illustrate the human control over nature, including one's own body; moreover, in taking control of nature and modifying the body, it is suggested that the individual can release the body's inner, superior, nature. One's inner whiteness is released, illuminating the skin. 


\section{Conclusion}

The European invention of whiteness and its American institutionalization are based on an opposition to the black other and bestow on the individual body a number of assigned societal values of whiteness or blackness. The Asian construction of whiteness is grounded in a hierarchy of the social body and projects shades of whiteness on the individual skin. Beyond the presumably distinctive traditions of embodiment in the East and West (Turner 7), whether assumed by the self and protected by borders or assigned to the other (within) and attainable by what Foucault called "technologies of the self," the power of whiteness continues to insinuate itself. Indeed, it appears that, beyond cultural variations, the desire for light skin is nearly universal (Russell et al. 41).

In an article arguing that the white body in Asia is a transnational construct, "cosmopolitan whiteness" is proposed as a mode for rethinking whiteness beyond racial and ethnic categories (Saraswati). However, the civilized cosmopolitan body merely recycles racial and ethnic whiteness for today's globalized world. Nevertheless, a passing point in the same article is worth emphasizing as regards the invention of whiteness in Europe, America and Asia: virtuality that comes from a lack of a material substance: whiteness is neither real, nor unreal. A signifier without a signified body, whiteness can accommodate any somatic ideal, it can apply to humans from Asia through Europe to America; it can equally incorporate the conquering other and the conquered self.

That is because white, as a skin tone, does not exist; skin is fair, medium, olive or dark, as any cosmetologist could explain. Eventually, the Greek, Elizabethan or Japanese women painting their faces were displaying a virtual whiteness that had no equivalent in real life and bodies: it was a mask of difference. As anthropologist Nestor Castro argued against the grain, "there is a universal pattern in humanity that says that the more different you are from the common, the more you are beautiful" (Castro qtd. in Pan 19). In fact, white is not even a color. In the visual spectrum, white reflects light and is the presence of all colors. Etymologically, white means light and bright (Harper); to be white is to be bright, to irradiate the divine light. This common, mystical symbolism of whiteness takes a scientific guise in the earliest combination of theology and technology: alchemy. In alchemy, whiteness, albedo, is one of the four major stages of the magnum opus, the process of creating the philosopher's stone, along with blackness (nigredo), yellowness (citrinitas), and redness (rubedo). Incidentally, this color terminology was employed by Carolus Linneus, in one of the first models of racial classification, to distinguish beween the European, the African, the Asian and the American in the eighteenth century. Following the chaos of the stage of blackness, the alchemist undertakes a washing away of impurities, in whiteness. In this process, the subject is divided into two opposing 
principles to be later coagulated in the yellow stage in order to form a unity of opposites or coincidentia oppositorum in the red stage (Broek 158). The albedo phase has been interpreted, mystically and/or scientifically, as corresponding to a spiritualization of matter; the goal is to regain the original purity and receptivity of the soul (Burckhardt 183-9). Nevertheless, one should bear in mind that whiteness is not the end of the alchemist's work, but just one step in the process of illuminating matter.

The human mind's mystical fixation with the purity of whiteness was justified by philosophy, sanctioned by science, upheld by technology, and has materialized in abusive social practices and domineering cultural assumptions. Alchemy is the more abstract example of an enduring ideology merging mysticism and science; skin-whitening creams are its more concrete samples. From ancient through medieval to contemporary times, whiteness was inscribed on the human body, beyond the surface of the skin, as a virtual sign of difference, superiority and divine brightness, based on a common global symbolism with complex and localized historical consequences, often ignorant of the fact that, in the end, light is the presence of all colors.

\section{Works Cited}

Appiah, Anthony. "The Uncompleted Argument: Du Bois and the Illusion of Race." "Race" Writing and Difference. Ed. Henry Louis Gates, Jr. 21-37. Chicago and London: U. of Chicago P., 1985. Print.

Ashikari, Mikiko. "Cultivating Japanese Whiteness: The "Whitening" Cosmetics Boom and Japanese Identity." Journal of Material Culture 10 (Mar. 2005): 73-91. Print.

Baldwin, James. Notes of a Native Son. New York: Dial Press, 1963. Print.

Berge, Pierre van den, and Peter Frost. "Skin Color Preference, Sexual Dimorphism, and Sexual Selection: A Case of Gene Culture Co-evolution?" Ethnic and Racial Studies 9 (1986): 87-113. Print.

Blumenbach, Johann Friedrich. De generis humani varietate nativa, 3rd edn. (1795), qtd. in Susanne Zantop, "The Beautiful, the Ugly, and the German: Race, Gender and Nationality in Eighteenth-Century Anthropological Discourse." Gender and Germanness: Cultural Productions of Nation. Ed. Patricia Herminghouse and Magda Mueller. 21-36. Oxford: Berghahn, 1998. Print.

Bonilla-Silva, Eduardo. "The Invisible Weight of Whiteness: the Racial Grammar of Everyday Life in Contemporary America." Ethnic and Racial Studies, 35.2 (2012): 173-194. Print.

Bourdieu, Pierre. Distinction: A Social Critique of the Judgment of Taste. Cambridge, MA: Harvard UP., 1984. Print.

Broek, Roelof van den, and Wouter J. Hanegraaff. Gnosis and Hermeticism from Antiquity to Modern Times. New York: State U. of New York P., 1998. Print.

Burckhardt, Titus. Alchemy: Science of the Cosmos - Science of the Soul. Trans. William Stoddart, Baltimore: Penguin Books, 1967. Print. 
Burgin, Say. "Locating Douglass Fitch: The Roots of Color and Activist Traditions of United States Critical Whiteness Studies." Critical Race and Whiteness Studies, 9.1 (2013): 1-19. Print.

Castro, Nestor. "Asia's Obsession with White Skin Leaves a Black Mark." Asian Pacific Post, 5 Nov. 2006. Web. 13 Jun. 2015.

Chada, Rhada and Paul Husband. The Cult of the Luxury Brand: Inside Asia's Love Affair with Luxury. Boston: Nicholas Brealey Publishing, 2007. Print.

Cross, William E., Jr. Shades of Black: Diversity in African-American Identity. Philadelphia: Temple UP., 1991. Print.

DuBois, William Edward Burghard. The Conservation of Races and the Negro. 1897. A Penn State University Electronic Classics Series Publication. earlwright2.com (2007). Web. 13 Jun. 2015.

Dyer, Richard. White. London: Routledge, 1997. Print.

Dyson, Michael Eric. Reflecting Black: African-American Cultural Criticism. Minneapolis: U. of Minnesota P., 1993. Print.

Eagleton, Terry. "Nationalism: Irony and Commitment." 1988. Nationalism, Colonialism and Literature. 23-40. Minneapolis: U. of Minnesota P., 1990. Print.

Fanon, Frantz. Black Skin, White Masks. Trans. Charles Lam Markmann. New York: Grove Press, 1967. Print.

Fuller, Thomas. "A Vision of Pale Beauty Carries Risks for Asia's Women.” New York Times, 14 May 2006. Print.

Goon, Patricia, and Allison Craven. "Whose Debt? Globalization and Whitefacing in Asia." Intersections: Gender, History and Culture in the Asian Context, 9 (Aug. 2003). murdoch.edu.au. Web. 13 Jun. 2015.

Grubow, Liz. "Marketing Matters: Chinese Culture and its Effect on Skin Care Trends in China." GCIMagazine.com, 5 Sep. 2008. Web. 12 Jun. 2015.

Hall, Roland E. "The Bleaching Syndrome: African Americans' Response to Cultural Domination Vis-à-vis Skin Color.” Journal of Black Studies, 26.2 (1995): 172-84. Print.

Harper, Douglas. Online Etymology Dictionary (2001), Web. 12 Jun. 2015.

Henderson, Carol E. Scarring the Black Body: Race and Representation in African American Literature. Columbia: U. of Missouri P., 2002. Print.

Hoetink, Harry. The Two Variants in Caribbean Race Relations. London: Oxford UP., 1967. Print.

hooks bell. "Postmodern Blackness." Postmodern Culture 1.1 (Sep. 1990). africa.upenn.edu. Web. 19 Apr. 1994.

hooks, bell. Black Looks: Race and Representation. Boston: South End, 1992. Print.

hooks, bell. Yearning: Race, Gender and Cultural Politics. New York: Vintage, 1989. Print.

Humes, Karen, Nicholas A. Jones, and Roberto R. Ramirez. "Overview of Race and Hispanic Origin: 2010.” 2010 Census Briefs. Mar. 2011. Web. 12 Jun. 2015.

Jockey, Philippe. Le Mythe de la Grèce Blanche. Histoire d'un rêve occidental. Paris: Belin, 2013. Print.

Leistikow, Nicole. "Indian Women Criticize 'Fair and Lovely' Ideal." Women's eNews 28 Apr. 2003. Web. 11 Jun. 2015.

Leonardo, Zeus. "The Color of Supremacy: Beyond the Discourse of 'White Privilege'." Educational Philosophy and Theory 36.2 (2004): 137-152. Print. 
Li, Eric P. H., Hyun Jeong Min, Russell W. Belk, Junko Kimura, and Shalini Bahl. "Skin Lightening and Beauty in Four Asian Cultures." Advances in Consumer Research 35 (2008): 444-449. Print.

Locke, Alain. "The Negro in American Culture." Black Voices. Ed. Abraham Chapman. 532-58. New York: New American Library, 1968. Print.

Lorde, Audre. "Age, Race, Class, and Sex: Women Redefining Difference." Race, Class, and Gender: An Anthology. Ed. Margaret Andersen and Patricia Hill Collins. 495-502. Belmont: Wadsworth, 1992. Print.

McLaren, Peter. "White Terror and Oppositional Agency: Towards a Critical Multiculturalism." Multiculturalism. A Critical Reader. Ed. David Theo Goldberg. 46-73. Oxford: Blackwell, 1995.

Miller, Laura. Beauty Up: Exploring Contemporary Japanese Body Aesthetics. Berkeley: U. of California P., 2006. Print.

Morrison, Toni. Playing in the Dark: Whiteness and the Literary Imagination. New York: Vintage Books, 1993. Print.

Nayak, Anoop. “Critical Whiteness Studies.” Sociology Compass 1.2 (2007): 737-55. Print.

Nelson, Dana. Word in Black and White: Reading "Race” in American Literature, 16381867. New York: Oxford UP., 1993. Print.

Painter, Nell Irvin. "Why White People are Called 'Caucasian'?" Collective Degradation: Slavery and the Construction of Race. Proceedings of the Fifth Annual Gilder Lehrman Center International Conference at Yale University. 2003. Yale.edu. Web. 14 Jun. 2015.

Pan, Elysia. Beautiful White: An Illumination of Asian Skin-Whitening Culture. PhD Diss. Duke U., Apr. 2013. Print.

Roediger, David. Towards the Abolition of Whiteness. Essays on Race, Politics and Working Class History. London: Verso, 1994. Print.

Russell, Kathy, Midge Wilson, and Ronald E. Hall. The Color Complex: The Politics of Skin Color among African Americans. New York: Harcourt Brace Jovanovich, 1992. Print.

Rutherford, Jonathan. "A Place Called Home: Identity and Cultural Politics of Difference.” Identity: Community, Culture, Difference. Ed. Jonathan Rutherford. 9-27. London: Lawrence \& Wishart, 1990. Print.

Saraswati, L. Ayu. "Cosmopolitan Whiteness: The Effects and Affects of SkinWhitening Advertisements in a Transnational Women's Magazine in Indonesia." Meridians: Feminism, Race, Transnationalism 10.2 (2010): 15-41. Print.

Snowden, Frank M. Before Color Prejudice. Cambridge, MA: Harvard UP., 1983. Print.

Steyn, Melissa and Daniel Conway. "Introduction: Intersecting Whiteness, Interdisciplinary Debates." Ethnicities 10.3 (2010): 283-291. Print.

Tungate, Mark, Branded Beauty: How Marketing Changed the Way We Look. Philadelphia: Kogan Page, 2011. Print.

Turner, Bryan and Zheng Yangwen. The Body in Asia. Oxford: Berghahn, 2009. Print.

Wagatsuma, Hiroshi. "The Social Perception of Skin Color in Japan." Daedalus, 96.2 (1967): 407-43. Print.

West, Cornel. "The New Cultural Politics of Difference”. October 53 (1990): 93-109. Print. 